\title{
Molecular detection of hemotrophic mycoplasmas among domiciled and free-roaming cats in Campo Grande, state of Mato Grosso do Sul, Brazil
}

Detecção molecular de micoplasmas hemotróficos em gatos domiciliados e errantes em Campo Grande, estado do Mato Grosso do Sul, Brasil

Ana Cláudia Gabriela Alexandre de Santis ${ }^{1}$; Heitor Miraglia Herrera²; Keyla Cartens Marques de Sousa ${ }^{1}$;

Luiz Ricardo Gonçalves ${ }^{1}$; Nathani Cristina Baccarim Denardi ${ }^{1}$; Iara Helena Domingos ${ }^{3}$; João Bosco Vilela Campos²; Rosangela Zacarias Machado'; Marcos Rogério André ${ }^{*}$

${ }^{1}$ Universidade Estadual Paulista - UNESP, Jaboticabal, SP, Brazil

${ }^{2}$ Universidade Católica Dom Bosco - UCDB, Campo Grande, MS, Brazil

${ }^{3}$ Centro de Controle de Zoonoses - CCZ, Campo Grande, MS, Brazil

Received March 11, 2014

Accepted April 22, 2014

\begin{abstract}
Hemoplasmas are bacteria living in feline red blood cells. Feline hemoplasmosis is frequently associated with old male cats that have access to the streets. This study aimed to detect the presence of hemoplasma speciess in domiciled and free-roaming cats in Campo Grande, state of Mato Grosso do Sul (MS), Brazil, using molecular techniques. Between January 2013 and April 2013, EDTA-whole blood samples were collected from 151 domestic cats (65 free-roaming and 86 domiciled cats). Samples were subjected to PCR assays targeting hemoplasmas $16 \mathrm{~S}$ rRNA, followed by sequencing, BLAST analysis and phylogenetic analysis. Results show an occurrence of $36.4 \%$ for hemoplasmas. Twenty-three cats (15.2\%) were positive for 'Candidatus Mycoplasma haemominutum', 17 (11.2\%) for M. haemofelis and 15 (9.9\%) for 'Candidatus M. turicensis', from PCR. Coinfection by two or three hemoplasmas was found in 25 cats (16.6\%). No statistically significant difference between genders or between lifestyles was observed for the presence of hemoplasmas among the cats. Results show different hemoplasma species are present in cat population (Campo Grande, MS, Brazil). It is suggested that a differential diagnosis for feline hemoplasmosis should be made when cats show nonspecific clinical signs of disease with systemic manifestation.
\end{abstract}

Keywords: Feline hemoplasmosis, hemoplasmas, molecular diagnosis, central-western Brazil.

\section{Resumo}

Hemoplasmas são bactérias encontradas aderidas aos eritrócitos de felinos. A hemoplasmose felina está frequentemente associada a gatos velhos machos, sem raça definida e com acesso à rua. O presente estudo objetivou realizar a detecção molecular de espécies de hemoplasmas em gatos domiciliados e errantes em Campo Grande, estado do Mato Grosso do Sul (MS), Brasil. Entre janeiro/2013 e abril/2013, amostras de sangue foram colhidas de 151 gatos domésticos (65 errantes e 86 domiciliados) e avaliadas por PCR frente à presença de sequências do gene do $16 \mathrm{~S}$ rRNA de hemoplasmas, seguidas de sequenciamento, análise pelo BLAST e análise filogenética. Os resultados deste estudo mostraram uma ocorrência de $36,4 \%$. Vinte e três $(15,2 \%)$ gatos mostraram-se positivos na PCR para 'Candidatus Mycoplasma haemominutum', 17 (11,2\%) para Mycoplasma haemofelis, e 15 (9,9\%) para 'Candidatus Mycoplasma turicensis'. A co-infecçáo por dois ou três hemoplasmas ocorreu em 25 gatos (16,6\%). Não foi observada diferença estatística significativa entre sexo e estilo de vida dos gatos amostrados e a presença de hemoplasmas. $\mathrm{O}$ estudo mostrou que diferentes espécies de hemoplasmas circulam na população de gatos (domiciliados e errantes) na cidade de Campo Grande, MS, Brasil. Sugere-se o diagnóstico diferencial para hemoplasmose felina em gatos que apresentam sinais clínicos inespecíficos de doença com manifestação sistêmica.

Palavras-chave: Hemoplasmose felina, hemoplasmas, diagnóstico molecular, centro-oeste brasileiro.

\footnotetext{
*Corresponding author: Marcos Rogério André

Laboratório de Imunoparasitologia, Departamento de Patologia Veterinária, Faculdade de Ciências Agrárias e Veterinárias, Universidade Estadual Paulista "Júlio de Mesquita Filho" - UNESP, Campus de Jaboticabal, Via de Acesso Prof. Paulo Donato Castellane, s/n, Zona Rural, CEP 14884-900, Jaboticabal, SP, Brasil

e-mail: marcos_andre@fcav.unesp.br
} 


\section{Introduction}

Hemotropic mycoplasmas (hemoplasmas) are bacteria of small size and genome that are found attached to the cytoplasmic membrane of red blood cells (TASKER, 2010). A range of hemoplasmas can infect cats: Mycoplasma haemofelis, 'Candidatus M. haemominutum', 'Candidatus M. turicensis' and 'Candidatus M. haematoparvum' (TASKER, 2010; SYKES, 2010). Among feline hemoplasma species, $M$. haemofelis is mainly associated with clinical disease, often during in acute infection (TASKER, 2010). Cats infected by $M$. haemofelis often show prostation, inappetence and dehydration; in some clinical cases, weight loss is also reported. 'Candidatus M. haemominutum' and 'Candidatus M. turicensis' may cause anemia only when concurrent disease is present and/or a condition of immunosuppression. Anemia, which is frequently found in hemoplasma-infected cats, is manifested by weakness, mucosal pallor, tachycardia, tachypnea and, occasionally, syncope or neurological signs (TASKER et al., 2009; SYKES, 2010).

Feline hemoplasma infection has been correlated with male gender, non-pedigree status, and access to the outdoors (SYKES, 2010). Although fleas have been incriminated as potential vectors for hemotropic mycoplasmas, experimental attempts to transmit hemoplasmas among cats by these arthropods were inconclusive (WOODS et al., 2006). Direct transmission through biting and fighting is emerging as a possible mode of transmission (SYKES, 2010).

The laboratory diagnosis of feline hemoplasmosis is based on blood smear examinations and PCR assays. False positive diagnoses are frequently found in cytological preparations containing stain precipitate, basophilic stippling and HowellJolly bodies. Also, fresh smears should preferentially be examined, because parasites may detach from erythrocytes in the presence of ethylenediaminetetraacetic acid (EDTA). PCR assays are significantly more sensitive than blood smear evaluation (SYKES, 2010).

Hemoplasma infections among cats have been reported in some areas in Brazil over the last decade (MACIEIRA et al., 2008; DE BORTOLI et al., 2012; BRAGA et al., 2012; MICELI et al., 2013). Because of the potential risk to human health (SANTOS et al., 2008), the present study aimed to clarify the epidemiology of hemoplasmas in domiciled and free-roaming cats in Campo Grande, state of Mato Grosso do Sul (MS), Brazil.

\section{Material and Methods}

Between January and April 2013, whole blood samples were collected by convenience from 151 cats $(54$ males, 95 females and two without gender registration) in the city of Campo Grande, which is the capital of the state of Mato Grosso do Sul, Brazil. Free-roaming non-domiciled cats $(n=65)$ were caught by technical staff from the local zoonosis control center (CCZ). Domiciled cats $(n=86)$ were sampled during pre-surgical procedures for a castration project at the CCZ; these animals were returned to their homes after surgery. Overall, the domiciled cats were in a better physical condition than the non-domiciled animals. The blood samples were collected in EDTA and stored at $-20^{\circ} \mathrm{C}$ until DNA extraction.
DNA was extracted from $200 \mu \mathrm{L}$ of each whole blood sample using the QIAamp DNA blood mini-kit (QIAGEN ${ }^{\bullet}$, Valencia, California, USA), in accordance with the manufacturer's instructions.

Each DNA sample was subjected to PCR assays targeting the 16S rRNA gene of $M$. haemofelis (393 bp) (BERENT et al., 1998), 'Candidatus M. haemominutum' (130 bp) (FOLEY et al., 1998) and 'Candidatus M. turicensis' (488 bp) (SANTOS et al., 2009). Samples that were positive for $M$. haemofelis and 'Candidatus M. haemominutum' were subjected to another PCR protocol (CRIADO-FORNELIO et al., 2003), in which primers amplify a fragment of 600 bp. Mycoplasma haemofelis, 'Candidatus M. haemominutum' and 'Candidatus M. turicensis' DNA obtained from blood samples from naturally infected cats in São Luis, Maranhão, Brazil (BRAGA et al., 2012) were used as positive DNA controls in PCR reactions for hemoplasmas. The reaction products were purified using the Silica Bead DNA gel extraction kit (Fermentas, São Paulo, SP, Brazil). Purified amplified DNA fragments from positive samples were subjected to sequencing for confirmation in an automatic sequencer (ABI Prism 310 genetic analyzer; Applied Biosystems/Perkin-Elmer) and were used for subsequent phylogenetic analysis. The phylogenetic reconstructions were based upon deoxyribonucleic acid. Consensus sequences were obtained through the analysis of the products from sequencing from both forward and reverse olygonucleotides using the CAP3 program (http://mobyle.pasteur.fr/cgi-bin/MobylePortal/portal.py) (ALTSCHUL et al., 1990). Comparisons with sequences deposited in GenBank were made using the basic local alignment search tool (BLAST $^{\oplus}$ ). The CLUSTAL W software (THOMPSON et al., 1994) and MEGA software (KUMAR et al., 2004) were used for alignment and phylogenetic analysis, respectively. The maximum likelihood distance method was used to build the phylogenetic tree (SAITOU; NEI, 1987) using the Kimura two-parameter model. The bootstrap test with 1000 replications was repeated in order to estimate the confidence of the branching patterns of the neighbor-joining tree (FELSENSTEIN, 1985).

The variables (origin of the sampled cats [domiciled or freeroaming] and gender) were correlated with the hemoplasma-PCR results using the GraphPad Prism ${ }^{\circledast}$ software, version 5.00.288. For this purpose, we used the two-factor analysis of variance method followed by the Bonferroni test, taking the confidence interval to be $95 \%$.

\section{Results}

PCR results showed an overall molecular occurrence of 36.4\% (55/151). Twenty-three cats (15.2\%) (11 domiciled and 12 free-roaming cats) were positive for 'Candidatus M. haemominutum', 17 (11.2\%) (nine domiciled and eight free-roaming) for $M$. haemofelis and 15 (9.9\%) (nine domiciled and six free-roaming) for 'Candidatus M. turicensis'. Regarding coinfections by different hemoplasma species, we found that the occurrence rate was 16.6\%: nine cats $(5.9 \%$ ) (four domiciled and five free-roaming) were coinfected by $M$. haemofelis and 'Candidatus M. haemominutum'; six cats (3.9\%) (four domiciled and two free-roaming) were coinfected by $M$. haemofelis and 'Candidatus M. turicensis'; seven cats (4.6\%) (four domiciled and three free- 
roaming) were coinfected by 'Candidatus $\mathrm{M}$. haemominutum' and 'Candidatus M. turicensis'; and three cats (1.9\%) (one domiciled and two free-roaming) were coinfected by $M$. haemofelis, 'Candidatus M. haemominutum' and 'Candidatus M. turicensis' (Table 1). The sequencing followed by the phylogenetic analysis based on $16 \mathrm{~S}$ rRNA (Table 2; Figure 1) confirmed that the sampled cats were parasitized by $M$. haemofelis, Candidatus M. haemominutum and Candidatus M. turicensis. No statistically significant difference between genders or lifestyles among the sampled cats was correlated with positivity in PCR assays for hemoplasmas $(P>0.05)$.

\section{Discussion}

Although hemoplasma infection has been documented in cats in several regions of Brazil (DE MORAIS et al., 2007; MACIEIRA et al., 2008; SANTOS et al., 2009; BRAGA et al., 2012; DE BORTOLI et al., 2012; MICELI et al., 2013), few reports clarifying actual epidemiology have yet been published (BIONDO et al., 2009). These organisms have been reported in cats in the states of Paraná (three cats showing clinical signs of hemoplasmosis) (DE MORAIS et al., 2007), Rio de Janeiro (cats attended at veterinary clinics) (MACIEIRA et al., 2008), Rio Grande do Sul (non-hospitalized pet cats screened for blood donation and feral cats housed in a local shelter) (SANTOS et al., 2009), Maranhão (domiciled cats with outdoor access) (BRAGA et al., 2012), São Paulo (domiciled cats subjected to a spaying/neutering program) (DE BORTOLI et al., 2012) and Mato Grosso (cats housed in animal shelters) (MICELI et al., 2013). Among wild carnivores, hemotrophic mycoplasmas have been molecularly detected in wild felids maintained in captivity in zoos and institutions in the Federal District (ANDRÉ et al., 2011) and the states of Paraná (GUIMARÁES et al., 2007) and São Paulo (ANDRÉ et al., 2011).

The most prevalent hemoplasma found in the present study was 'Candidatus M. haemominutum'. In most studies around the world, 'Candidatus M. haemominutum' has been the most common hemoplasma found, followed by 'Candidatus M. turicensis' and M. haemofelis (SYKES et al., 2007a, b). Herein, the molecular occurrence of $M$. haemofelis was higher than that found for 'Candidatus M. turicensis'. The rates of occurrence of feline hemoplasmas vary greatly between different populations (healthy vs. sick; feral vs. pet) (BARKER; TASKER, 2013): $M$. haemofelis occurrence has ranged from 0.4 to $46.6 \%$ (SYKES et al., 2007a; KAMRANI et al., 2008), 'Candidatus Mycoplasma haemominutum' from 8.1 to $46.7 \%$ (FUJIHARA et al., 2007; ROURA et al., 2010), 'Candidatus Mycoplasma turicensis' from 0.1 to $26 \%$ (WILLI et al., 2006b; KAMRANI et al., 2008) and 'Candidatus M. haematoparvum'-like from 0 to $0.7 \%$ (SYKES et al., 2007a). Since the protocol described by Foley et al. (1998) does not not allow to discriminate between 'Candidatus Mycoplasma haemominutum' and 'Candidatus M. haematoparvum', some non-sequenced samples showing positive results in this protocol

Table 1. Number of cats with single or multiple hemoplasma infections by PCR according to origin and gender in Campo Grande, State of Mato Grosso do Sul, Brazil.

\begin{tabular}{|c|c|c|c|c|c|}
\hline \multirow{2}{*}{ Hemoplasma } & \multicolumn{2}{|c|}{ Domiciled cats } & \multicolumn{2}{|c|}{ Free-roaming cats } & \multirow{2}{*}{ Total (\%) } \\
\hline & Male & Female & Male & Female & \\
\hline$M f$ & 5 & 4 & 2 & 6 & $17(11.3)$ \\
\hline $\mathrm{CMhm}$ & 8 & 3 & 5 & 7 & $23(15.2)$ \\
\hline$C M t$ & 4 & 5 & 4 & 2 & $\begin{array}{c}15(9.9) \\
55(36.4)\end{array}$ \\
\hline Co-infection: & & & & & \\
\hline$M h+C M h m$ & 3 & 1 & 1 & 4 & $9(6)$ \\
\hline$M h+C M t$ & 1 & 3 & 1 & 1 & $6(4)$ \\
\hline$C M h m+C M t$ & 3 & 1 & 2 & 1 & $7(4.6)$ \\
\hline$M f+C M h m+C M t$ & 0 & 1 & 1 & 1 & $\begin{array}{c}3(2) \\
25(16.6)\end{array}$ \\
\hline
\end{tabular}

Mf = Mycoplasma haemofelis; CMhm= 'Candidatus Mycoplasma haemominutum'; CMt= 'Candidatus Mycoplasma turicensis'.

Table 2. Sequence analysis for the $16 \mathrm{~S}$ rRNA gene of hemoplasmas from domiciled and free-roaming cats in Campo Grande, State of Mato Grosso do Sul, Brazil,compared with sequences deposited in the GenBank database.

\begin{tabular}{|c|c|c|c|c|}
\hline Hemoplasmas & $\begin{array}{c}\text { Number of positive } \\
\text { animals }\end{array}$ & $\begin{array}{c}\text { Number of analysed } \\
\text { sequences }\end{array}$ & $\begin{array}{c}\text { Closest Genbank entry (by } \\
\text { BLAST }^{\oplus} \text { ) \% identity. - 16S } \\
\text { rRNA gene }\end{array}$ & $\begin{array}{c}\text { GenBank accession } \\
\text { numbers }\end{array}$ \\
\hline Mycoplasma haemofelis & 17 & 8 & $\begin{array}{l}\text { Mycoplasma haemofe- } \\
\text { lis - KC331019-99\% }\end{array}$ & KJ135313-KJ135320 \\
\hline $\begin{array}{l}\text { 'Candidatus Mycoplasma } \\
\text { haemominutum' }\end{array}$ & 23 & 8 & $\begin{array}{l}\text { ‘Candidatus M. } \\
\text { haemominu- } \\
\text { tum' - KC331022-99\% }\end{array}$ & KJ135321-KJ135328 \\
\hline $\begin{array}{l}\text { 'Candidatus Mycoplasma } \\
\text { turicensis' }\end{array}$ & 15 & 14 & $\begin{array}{l}\text { 'Candidatus M. turicen- } \\
\text { sis' - EU839977 - 99\% }\end{array}$ & KJ095684-KJ095697 \\
\hline
\end{tabular}




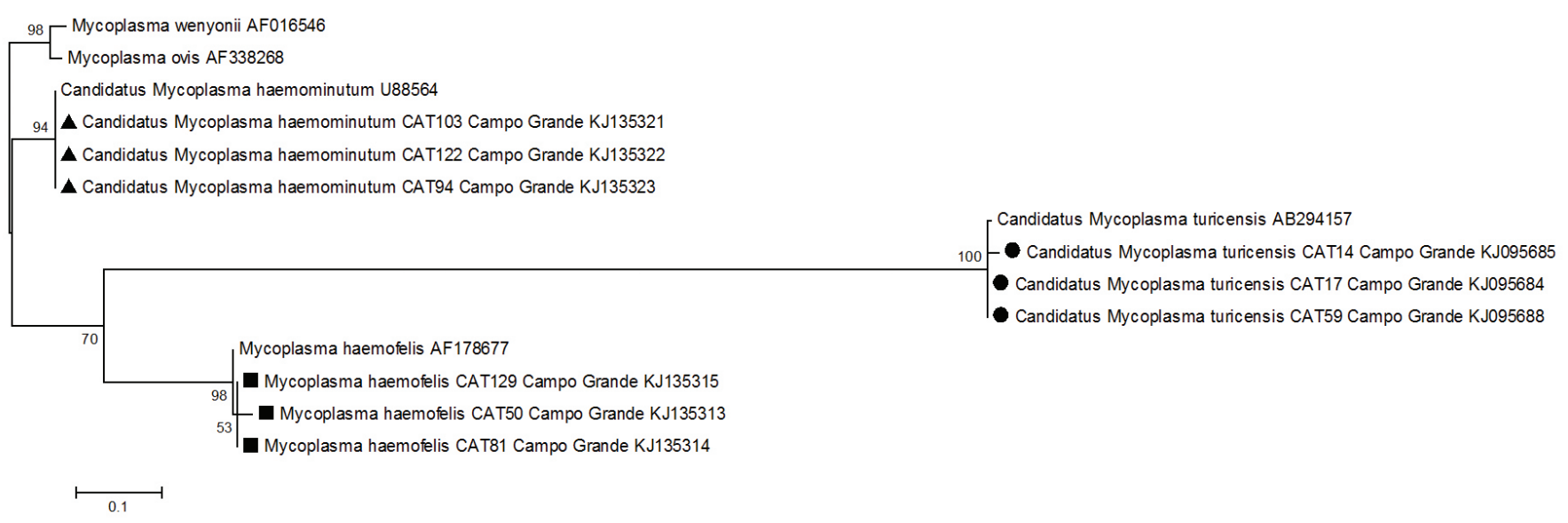

Figure 1. Phylogenetic comparisons of hemoplasmas detected in domestic cats from Campo Grande, MS, Brazil, and sequences deposited in the Genbank database, based on 16S rRNA gene sequences (480bp). The tree was constructed using the Maximum Likelihood Method and kimura-2 parameters model. The numbers on the tree indicate bootstrap values for the branch points. GenBank accession numbers are shown.

could be one of these two organisms, although the occurrence of 'Candidatus M. haematoparvum' among cats is considered too low.

Previous studies conducted in Brazil have focused on different cat populations, such as animals maintained in animal shelters (SANTOS et al., 2009; MICELI et al., 2013), domiciled cats with outdoor access (BRAGA et al., 2012), cats subjected to a spaying/neutering program (DE BORTOLI et al., 2012) and cats attended at veterinary clinics (MACIEIRA et al., 2008). The molecular occurrences of $M$. haemofelis (10.5\%), 'Candidatus M. haemominutum' (12.8\%) and 'Candidatus M. turicensis' $(10.5 \%)$ found in the present study among domiciled cats subjected to a spaying/neutering program in the CCZ of Campo Grande were higher than those found by de Bortoli et al. (2012) (2.2\%; $4.3 \% ; 2.2 \%$ ), who sampled a similar population of cats in the city of Jaboticabal, state of Sáo Paulo.

Furthermore, the molecular occurrences of $M$. haemofelis (12.3\%), 'Candidatus M. haemominutum' (18.5\%) and 'Candidatus M. turicensis' (9.2\%) found among free-roaming cats housed in the CCZ of the city of Campo Grande, state of Mato Grosso do Sul, were higher than those found among free-roaming cats maintained in animal shelters in the city of Cuiabá, state of Mato Grosso (2.2; 6.7; 0.5\%, respectively) (MICELI et al., 2013). The poor fitness observed among free-roaming cats, in comparison with domiciled cats, can be explained by the poor nutritional support and likely presence of coinfections in this cat population. The good fitness observed among hemoplasma-positive domiciled cats suggests that these animals probably are asymptomatic carriers of these pathogens.

It is noteworthy to state that Criado-Fornelio et al. (2003) PCR protocol was described previously to 'Candidatus M. turicensis' detection (WILLI et al., 2005), aiming to amplify a $16 \mathrm{~S}$ rRNA fragment $(600 \mathrm{pb})$ of $M$. haemofelis and 'Candidatus M. haemominutum'. Besides, Santos et al. (2009) described a conventional PCR aiming to amplify a $16 \mathrm{~S}$ rRNA fragment of 'Candidatus M. turicensis'. When we aligned primers designed by Criado-Fornelio et al. (2003) to $16 \mathrm{~S}$ rRNA 'Candidatus M. turicensis' sequence, a $595 \mathrm{pb}$ fragment can be amplified, similar to that found for M. haemofelis and 'Candidatus M. haemominutum'
(600 pb). We observed that samples positive to only 'Candidatus M. turicensis' when submitted to Criado-Fornelio et al. (2003) PCR protocol, showed negative results or positive results with bands showing low intensity in gel electrophoresis (data not shown). Another question to point out is that the sensitivity of PCR assays used in the present study was not assessed. This fact associated to the absence of internal controls (such as use of a PCR protocol to amplify the feline $28 \mathrm{~S}$ rRNA) are limitations of the present work.

Unlike our results, feline hemoplasma infection has reported to be correlated with male gender, non-pedigree status and access to the outdoors (SYKES et al., 2008; WILLI et al., 2006a, b; TASKER et al., 2003; GRINDEM et al., 1990; LURIA et al., 2004). Some studies (NASH; BOBADE, 1986; GRINDEM et al., 1990; HARRUS et al., 2002; MACIEIRA et al., 2008; SYKES et al., 2008; GENTILINI et al., 2009) but not others (WILLI et al., 2006a; DE BORTOLI et al., 2012) have shown an association between retrovirus infection and hemoplasmosis. Herein, 22 cats $(14.6 \%)$ were coinfected by two hemoplasmas and three $(1.9 \%)$ by three hemoplasmas. In agreement with our findings, coinfections with two or three feline hemoplasma species have also been reported (SYKES et al., 2008; WILLI et al., 2006a, b; FUJIHARA et al., 2007; PETERS et al., 2008; GENTILINI et al., 2009; TASKER et al., 2003; JENSEN et al., 2001; LOBETTI; TASKER, 2004; LURIA et al., 2004; DE BORTOLI et al., 2012; BRAGA et al., 2012; MICELI et al., 2013). The present study shows that hemoplasmas circulate among domiciled and stray cats in Campo Grande, State of Mato Grosso do Sul, in central-western Brazil. More than one third of the sampled cats living in the city of Campo Grande are found to be infected with hemoplasmas and hemoplasmosis, showing non-specific clinical signs such as pale mucous membranes, lethargy, weakness, tachycardia, dyspnea, tachypnea, hepatosplenomegaly, lymphadenopathy, depression, inappetence, dehydration, pica, pyrexia and weight loss. Moreover, hemoplasmas present a potential threat to public health, Therefore, hemoplasmosis needs to be included as a differential diagnosis whenever cats show manifestations of systemic disease. 


\section{Acknowledgments}

The authors would like to thank Fundação de Amparo à Pesquisa do Estado de São Paulo (FAPESP) for providing scholarship (2013/06016-6) and financial support (2013/09889-0), and CCZ/MS for technical assistence.

\section{References}

Altschul SF, Gish W, Miller W, Myers EW, Lipman DJ. Basic local alignment search tool. J Mol Biol 1990; 215(3): 403-410. http://dx.doi. org/10.1016/S0022-2836(05)80360-2

André MR, Adania CH, Allegretti SM, Machado RZ. Hemoplasmas in wild canids and felids in Brazil. J Zoo Wildl Med 2011; 42(2): 342-347. PMid:22946419. http://dx.doi.org/10.1638/2010-0198.1

Barker E, Tasker S. Haemoplasmas: lessons learnt from cats. $N Z$ Vet J 2013; 61(4): 184-192. PMid:23458414. http://dx.doi.org/10.1080/ 00480169.2013 .771760

Berent LM, Messick JB, Cooper SK. Detection of Haemobartonella felis in cats with experimentally induced acute and chronic infections, using a polymerase chain reaction assay. Am J Vet Res 1998; 59(10): 1215-1220. PMid:9781450.

Biondo AW, Dos Santos AP, Guimarães AM, Vieira RFC, Vidotto $\mathrm{O}$, Macieira DB, et al. A review of the occurrence of hemoplasmas (hemotrophic mycoplasmas) in Brazil. Rev Bras Parasitol Vet 2009; 18(3): 1-7. PMid:19772768. http://dx.doi.org/10.4322/ rbpv.01803001

Braga MSCO, André MR, Freschi CR, Teixeira MCA, Machado RZ. Molecular detection oh hemoplasma infection among cats from São Luís Island, Maranhão, Brazil. Braz J Microbiol 2012; 43(2): 569-575. PMid:24031865 PMCid:PMC3768807. http://dx.doi.org/10.1590/ S1517-83822012000200018

Criado-Fornelio A, Martinez-Marcos A, Buling-Saraña A, BarbaCarretero JC. Presence of Mycoplasma haemofelis, Mycoplasma haemominutum and piroplasmids in cats from southern Europe: a molecular study. Vet Microbiol 2003; 93(4): 307-317. http://dx.doi. org/10.1016/S0378-1135(03)00044-0

De Bortoli CP, André MR, Seki MC, Pinto AA, Machado RZ. Detection of hemoplasma and Bartonella species and co-infection with retroviruses in cats subjected to a spaying/neutering program in Jaboticabal, SP, Brazil. Rev Bras Parasitol Vet 2012; 21(3): 219-223. PMid:23070430. http:// dx.doi.org/10.1590/S1984-29612012000300008

De Morais HA, Guimarães AM, Vidotto O, Baumann A, Biondo AW, Messick JB. Co-infection with Mycoplasma haemofelis and 'Candidatus Mycoplasma haemominutum' in three cats from Brazil. J Feline Med Surg 2007; 9(6): 518-520. PMid:17693111. http://dx.doi.org/10.1016/j. jfms.2007.05.005

Felsenstein J. Confidence limits on phylogenies: an approach using the bootstrap. Evolution 1985; 39(4): 783-791. http://dx.doi. org/10.2307/2408678

Foley JE, Harrus S, Poland A, Chomel B, Pedersen NC. Molecular, clinical, and pathologic comparison of two distinct strains of Haemobartonella felis in domestic cats. Am J Vet Res 1998; 59(12): 15811588. PMid:9858411.
Fujihara M, Watanabe M, Yamada T, Harasawa R. Occurrence of 'Candidatus Mycoplasma turicensis' infection in domestic cats in Japan. J Vet Med Sci 2007; 69(10): 1061-1063. PMid:17984594. http://dx.doi. org/10.1292/jvms.69.1061

Gentilini F, Novacco M, Turba ME, Willi B, Bacci ML, HofmannLehmann R. Use of combined conventional and real-time PCR to determine the epidemiology of feline haemoplasma infections in northern Italy. J Feline Med Surg 2009; 11(4): 277-285. PMid:18790658. http:// dx.doi.org/10.1016/j.jfms.2008.06.008

Grindem CB, Corbett WT, Tomkins MT. Risk factors for Haemobartonella felis infection in cats. J Am Vet Med Assoc 1990; 196(1): 96-99. PMid:2295559.

Guimarães AMS, Javarouski ML, Bonat M, Lacerda O, Balbinotti B, Queiroz LGPB, et al. Molecular detection of Candidatus Mycoplasma haemominutum in a lion (Panthera leo) from a Brazilian zoological garden. Rev Inst Med Trop S Paulo 2007; 49(3): 195-196. PMid:17625699. http:// dx.doi.org/10.1590/S0036-46652007000300011

Harrus S, Klement E, Aroch I, Stein T, Bark H, Lavy E. Retrospective study of 46 cases of feline haemobartonellosis in Israel and their relationships with FeLV and FIV infections. Vet Rec 2002; 151(3): 82-85. PMid:12164225. http://dx.doi.org/10.1136/vr.151.3.82

Jensen WA, Lappin MR, Kamkar S, Reagan WJ. Use of a polymerase chain reaction assay to detect and differentiate two strains of Haemobartonella felis in naturally infected cats. Am J Vet Res 2001; 62(4): 604-608. PMid:11327472. http://dx.doi.org/10.2460/ajvr.2001.62.604

Kamrani A, Parreira VR, Greenwood J, Prescott JF. The prevalence of Bartonella, hemoplasma, and Rickettsia felis infections in domestic cats and in cat fleas in Ontario. Can J Vet Res 2008; 72(5): 411-419. PMid:19086373 PMCid:PMC2568045.

Kumar S, Tamura K, Nei M. MEGA 3: Integrated software for molecular evolutionary genetics analysis and sequence alignment. Brief Bioinform 2004; 5(2): 150-163. PMid:15260895. http://dx.doi. org/10.1093/bib/5.2.150

Lobetti RG, Tasker S. Diagnosis of feline haemoplasma infection using a real-time PCR assay. J S Afr Vet Assoc 2004; 75(2): 94-99. PMid:15456166. http://dx.doi.org/10.4102/jsava.v75i2.460

Luria BJ, Levy JK, Lappin MR, Breitschwerdt EB, Legendre AM, Hernandez JA, et al. Prevalence of infectious diseases in feral cats in Northern Florida. J Feline Med Surg 2004; 6(5): 287-296. PMid:15363760. http://dx.doi.org/10.1016/j.jfms.2003.11.005

Macieira DB, De Menezes RCAA, Damico CB, Almosny NRP, McLane HL, Daggy JK, et al. Prevalence and risk factors for hemoplasmas in domestic cats naturally infected with feline immunodeficiency virus and/or feline leukemia virus in Rio de Janeiro, Brazil. J Feline Med Surg 2008; 10(2): 120-129. PMid:17905624. http://dx.doi. org/10.1016/j.jfms.2007.08.002

Miceli NG, Gavioli FA, Gonçalves LR, André MR, Sousa VR, Sousa $\mathrm{KC}$, et al. Molecular detection of feline arthropod-borne pathogens in cats in Cuiabá, state of Mato Grosso, central-western region of Brazil. Rev Bras Parasitol Vet 2013; 22(3): 385-390. PMid:24142170. http:// dx.doi.org/10.1590/S1984-29612013000300011

Nash AS, Bobade PA. Haemobartonella felis infection in cats from the Glasgow area. Vet Rec 1986; 119(15): 373-375. http://dx.doi. org/10.1136/vr.119.15.373

Peters IR, Helps CR, Willi B, Hofmann-Lehmann R, Tasker S. The prevalence of three species of feline haemoplasmas in samples submitted 
to a diagnostics service as determined by three novel real-time duplex PCR assays. Vet Microbiol 2008; 126(1-3): 142-150. PMid:17689890. http://dx.doi.org/10.1016/j.vetmic.2007.06.017

Roura X, Peters IR, Altet L, Tabar MD, Barker EN, Planellas M, et al. Prevalence of hemotropic mycoplasmas in healthy and unhealthy cats and dogs in Spain. JVet Diagn Invest 2010; 22(2): 270-274. PMid:20224091. http://dx.doi.org/10.1177/104063871002200219

Saitou N, Nei M. The neighbor-joining method: a new method for reconstructing phylogenetic trees. Mol Biol Evol 1987; 4(4): 406-425. PMid:3447015.

Santos AP, Dos Santos RP, Biondo AW, Dora JM, Goldani LZ, De Oliveira ST, et al. Hemoplasma infection in HIV-positive patient, Brazil. Emerg Infect Dis 2008; 14(12): 1922-1924. PMid:19046522 PMCid:PMC2634649. http://dx.doi.org/10.3201/eid1412.080964

Santos AP, Messick JB, Biondo AW, Oliveira ST, Pedralli V, Lasta CS, et al. Design, optimization, and application of a conventional PCR assay with an internal control for detection of "Candidatus Mycoplasma turicensis" 16S rDNA in domestic cats from Brazil. Vet Clin Pathol 2009; 38(4): 443-452. PMid:19548972. http://dx.doi. org/10.1111/j.1939-165X.2009.00158.x

Sykes JE. Feline hemotropic mycoplasmas. Vet Clin North Am Small Anim Pract 2010; 40(6): 1157-1170. PMid:20933142. http://dx.doi. org/10.1016/j.cvsm.2010.07.003

Sykes JE, Drazenovich NL, Ball LM, Leutenegger CM. Use of conventional and real-time polymerase chain reaction to determine the epidemiology of hemoplasma infections in anemic and nonanemic cats. J Vet Inter Med 2007a; 21(4): 685-693. PMid:17708387. http://dx.doi. org/10.1111/j.1939-1676.2007.tb03009.x

Sykes JE, Drazenovich NL, Kyles AE, Ball LM, Leutenegger CM. Detection of mixed infections with "Candidatus Mycoplasma haemominutum" and Mycoplasma haemofelis using real-time Taqman polymerase chain reaction. J Vet Diagn Invest 2007b; 19(3): 250-255. PMid:17459853. http://dx.doi.org/10.1177/104063870701900304

Sykes JE, Terry JC, Lindsay LL, Owens SD. Prevalences of various hemoplasma species among cats in the United States with possible hemoplasmosis. J Am Vet Med Assoc 2008; 232(3): 372379. PMid:18241101. http://dx.doi.org/10.2460/javma.232.3.372

Tasker S, Binns SH, Day MJ, Gruffydd-Jones TJ, Harbour DA, Helps $\mathrm{CR}$, et al. Use of a PCR assay to assess the prevalence and risk factors for
Mycoplasma haemofelis and "Candidatus Mycoplasma haemominutum" in cats in the United Kingdom. Vet Rec 2003; 152(7): 193-198. PMid:12620033. http://dx.doi.org/10.1136/vr.152.7.193

Tasker S. Haemotropic mycoplasmas: what's their real significance in cats? J Feline Med Surg 2010; 12(5): 369-381. PMid:20417898 PMCid:PMC2880789. http://dx.doi.org/10.1016/j.jfms.2010.03.011

Tasker S, Peters IR, Papasouliotis K, Cue SM, Willi B, HofmannLehmann R, et al. Description of outcomes experimental infection with feline haemoplasmas: copy numbers, haematology, Coombs' testing and blood glucose concentrations. Vet Microbiol 2009; 139(3-4): 323-332. PMid:19615832 PMCid:PMC2771275. http://dx.doi.org/10.1016/j. vetmic.2009.06.028

Thompson JD, Higgins DG, Gibson TJ. CLUSTAL W: improving the sensitivity of progressive multiple sequence alignment through sequence weighting, position specific gap penalties and weight matrix choice. Nucleic Acids Res 1994; 22(22): 4673-4680. PMid:7984417 PMCid:PMC308517. http://dx.doi.org/10.1093/nar/22.22.4673

Willi B, Boretti FS, Cattori V, Tasker S, Meli ML, Reusch C, et al. Identification, molecular characterization, and experimental transmission of a new hemoplasma isolate from a cat with hemolytic anemia in Switzerland. J Clin Microbiol 2005; 43(6): 2581-2585. PMid:15956367 PMCid:PMC1151947. http://dx.doi.org/10.1128/JCM.43.6.25812585.2005

Willi B, Boretti FS, Baumgartner C, Tasker S, Wenger B, Cattori $\mathrm{V}$, et al. Prevalence, risk factor analysis, and follow-up of infections caused by three feline hemoplasma species in cats in Switzerland. J Clin Microbiol 2006a; 44(3): 961-969. PMid:16517884 PMCid:PMC1393118. http://dx.doi.org/10.1128/JCM.44.3.961969.2006

Willi B, Tasker S, Boretti FS, Doherr MG, Cattori V, Meli ML, et al. Phylogenetic analysis of "Candidatus Mycoplasma turicensis" isolates from pet cats in the United Kingdom, Australia, and South Africa, with analysis of risk factors for infection. J Clin Microbiol 2006b; 44(12): 4430-4435. PMid:17035497 PMCid:PMC1698426. http://dx.doi.org/10.1128/ JCM.00987-06

Woods JE, Wisnewski N, Lappin MR. Attempted transmission of Candidatus Mycoplasma haemominutum and Mycoplasma haemofelis by feeding cats infected Ctenocephalides felis. Am J Vet Res 2006; 67(3): 494497. PMid:16506915. http://dx.doi.org/10.2460/ajvr.67.3.494 